\title{
Analysis of Factors Affecting The Timeliness of Financial Reporting on Manufacturing Companies in The Indonesia Stock Exchange
}

\author{
Jalilah IImiha ${ }^{1 *}$, Lusi Elviani Rangkuti ${ }^{2}$, Farida Khairani Lubis ${ }^{3}$ \\ Islamic University of North Sumatra ${ }^{1 * 2,3}$ \\ Corresponding Author: jalilah.ilmiha@fe.uisu.ac.id ${ }^{1)}$
}

Keywords: Timeliness; Debt To Equity Ratio;

Profitability; Company Size; Auditor Quality

\begin{abstract}
:
This study aims to find empirical evidence about the factors that affect the timeliness of financial reporting of manufacturing companies listed on the Indonesia Stock Exchange. The research uses quantitative research methods. The data collected in this study will be analyzed using two methods, namely 1) Descriptive statistical method, the analytical tool used is the average (mean) and standard deviation 2) Hypothesis Testing, hypothesis testing is done by using multivariate test using logistic regression. The sample from this study used 43 manufacturing companies $x$ in 3 years of research, 129 data on financial statements that were consistently listed on the Indonesia Stock Exchange for the period 2014-2016 were taken using the purposive sampling method. Based on Simultaneous Effect Analysis, it can be seen that $\alpha=$ 0.05 and degrees of freedom $(d f)=k=5$, where $k$ is the number of predictor variables, the value of $\chi^{2}(p)$ from the chi-square distribution table is 11.07048. Due to $6.266<$ 11.07048 or $-2(L O-L 1)<\chi_{(p)}^{2}$, it can be said that together (simultaneously), the five predictor variables (DER, ROA, $S I Z E, K A P, A U D C H)$ have no effect on the variable of timeliness of financial reporting.
\end{abstract}




\section{Introduction}

The development of the current capital market has increased very rapidly and of course in the future this investment business will become so complex, with a very tight level of competition, especially in the effort to provide and obtain information in every decision making. One of the important sources of information in the investment business in the capital market is the financial statements provided by every company that goes public (Nasarudin, 2017). Financial reporting is a vehicle for companies to communicate various economic measurement information regarding their resources and performance to various parties who have an interest in the information.

One of the important information for users related to financial statements is the company's profitability (Arniman Zebua et al., 2020). Users often make the company's profitability derived from financial statements as one of the indicators for the basis in making investment decisions (Simangunsong et al., 2018; Laoli \& Herawaty, 2019). Timeliness of financial reporting is an important characteristic for financial statements where financial statements that are reported on a timely basis will reduce asymmetric information (Sunarsih \& Dewi, 2019; Rafikaningsih et al., 2020). When the company delays financial reporting to the public, the information can no longer be used for decision making. The longer the delay in presenting a company's financial statements to the public, the more likely there is insider information about the company. If this happens, it will lead the market to no longer work properly (Imaniar, 2016).

One way to measure the transparency and quality of financial reporting is timeliness. The time span between the date of the company's financial statements and the date when the financial information is made public is related to the quality of the financial information reported. The demand for compliance with timeliness in submitting the financial statements of public companies in Indonesia has been regulated in Law No. 8 of 1995 concerning the capital market. The Capital Market and Financial Institution Supervisory Agency (Bapepam) also issued a special power of attorney Number: SKU-194/MK.01/2012 (Wardani, 2017). Bapepam also issued an attachment to the decisions of the Chairman of Bapepam and financial institutions regarding the submission of annual reports of issuers or public companies. The demand for compliance with timeliness in submitting the financial statements of public companies in Indonesia has been regulated in Law No. 8 of 1995 concerning the capital market (Kuswanto \& Manaf, 2013). Bapepam also issued a special power of attorney Number: SKU-194/MK.01/2012.

Bapepam also issued an attachment to the decision of the Chairman of Bapepam and financial institutions regarding the submission of the annual report of issuers or public companies Number: KEP-431/BL/2012 concerning the obligation to submit an annual report in accordance with the provisions of regulation Number X.K.6 as contained in the attachment to this decision which applies to the preparation of the annual report for the financial year ended on or after December 31 after the annual financial reporting date. This regulatory improvement is intended 
to enable investors to obtain financial information more quickly as a basis for making investment decisions and to adapt them to capital market developments (Nurmiati, 2016).

As a result, companies that are late in submitting financial reports in accordance with the provisions stipulated by Bapepam will be subject to administrative sanctions in accordance with applicable regulations (Dewi et al., 2019). For example, in 1997 Bapepam announced that it had officially issued a warning and imposed a fine of Rp. 2.98 billion to 170 companies for late submission of financial reports (Dwiyanti, 2010). The Indonesia Stock Exchange imposed sanctions by temporarily halting the trading of 8 stocks on October 31, 2017. The consequence of the delay in submitting the financial statements is that the temporary suspension of securities trading was imposed on the shares of PT Bakrie Telecom Tbk (BTEL), PT Borneo Lumbung Energi \& Metal Tbk (BORN), PT Eterindo Wahanatama Tbk (ETWA), PT.Ccapitalinc Investment Tbk (MTFN). ), PT Berau Coal Energy Tbk (BRAU), PT Evergreen Invesco Tbk (GREEN). PT Permata Prima Sakti Tbk (TKGA), PT Zebra Nusantara Tbk (ZBRA) in addition to being subject to suspension (temporary suspension) the Exchange has given a written warning III and an additional fine of Rp. $150,000,000$ to 8 listed companies that were late in submitting financial reports.

Researches that analyze the factors that cause companies to be unable to meet the timeliness of financial reporting have been carried out by several researchers, such as Dwiyanti (2010). She examined the factors that affect the timeliness of financial reporting of manufacturing companies listed on the Stock Exchange which found empirical evidence that delays in financial reporting were caused by the existence of profitability and ownership structure that had a positive effect on the timeliness of financial reporting of companies. Meanwhile, the Debt To Equity Ratio and auditor turnover have no effect on the timeliness of financial reporting. Utami \& Yennisa (2017) examine the factors that affect the timeliness of financial reporting in bank sub-sector companies on the Indonesia Stock Exchange. The results of the research are empirical evidence that firm size has a positive effect on the timeliness of financial reporting.

The factors that will be re-examined in this study are debt to equity ratio, profitability, and auditor turnover. What distinguishes this research from previous research is that this study included company size and auditor quality variables and to distinguish this study from previous researchers. The researcher only took manufacturing companies in the basic and chemical industrial sectors. There are 66 populations and there are differences in the years of research in auditing the annual financial statements of the research company taking the company's financial statements for 3 consecutive years, 2014, 2015, 2016. So that it encourages to re-examine the factors that affect the timeliness of the company's financial reporting. Therefore, these researchers aim to analyze factors affecting the timeliness of financial reporting on manufacturing companies listed on the Indonesia Stock Exchange. 


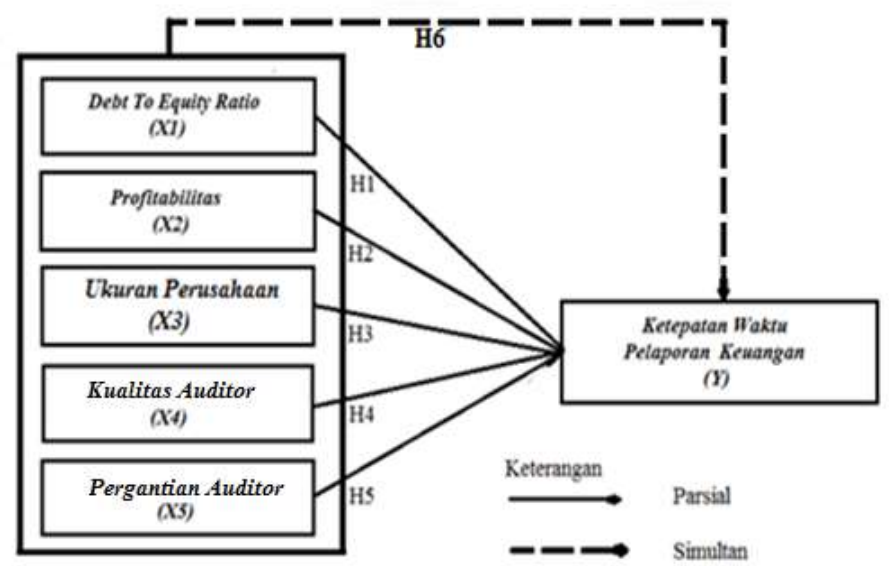

Figure 1. Theoretical Thinking Framework

\section{Research Method}

The data used in this study is secondary data, namely financial statement data on the Indonesia Stock Exchange in 2014-2016, manufacturing company data taken from the www.sahamok.co.id website and through the www.idx.co.id website. This was done to obtain data on the company's financial statements and variable data on debt to equity ratio, profitability, firm size, auditor quality and auditor turnover that affect the timeliness of financial reporting. As well as collecting previous research journals and literature studies to get the theories behind the research. The object of research is the factors that affect the timeliness of financial reporting in manufacturing companies listed on the Stock Exchange within a period of 3 consecutive years. 2014-2016. This research was conducted from January to April 2018.

Table 1. Research Variable

\begin{tabular}{|c|c|c|c|c|}
\hline Measured Variables & Indicator & Scale & $\begin{array}{l}\text { Data } \\
\text { source }\end{array}$ & Instrument \\
\hline $\begin{array}{l}\text { Dependent Variable } \\
\text { (Y) } \\
\text { Punctuality }\end{array}$ & $\begin{array}{l}\text { Number of days } \\
\text { required for audit } \\
\text { completion }\end{array}$ & Nominal & Secondary & $\begin{array}{l}\text { Date of } \\
\text { submission of } \\
\text { audited annual } \\
\text { financial report }\end{array}$ \\
\hline $\begin{array}{l}\text { Independent } \\
\text { Variable } \\
\text { (X1) }\end{array}$ & $\begin{array}{l}\text { Debt to Equity } \\
\text { Ratio }\end{array}$ & Ratio & Secondary & $\mathrm{LK}^{*}$ \\
\hline ratio & Return On Assets & Ratio & Secondary & LK* \\
\hline (X2) profitability & Measured as & Ratio & Secondary & LK* \\
\hline (X3) Company Size & $\begin{array}{l}\text { Logarithm of Total } \\
\text { Assets }\end{array}$ & Nominal & Secondary & $\mathrm{LK}^{*}$ \\
\hline
\end{tabular}


Cont. Table 1. Research Variable

\begin{tabular}{lllll}
\hline Measured Variables & \multicolumn{1}{c}{ Indicator } & Scale & $\begin{array}{c}\text { Data } \\
\text { source }\end{array}$ & Instrument \\
\hline (X4) Auditor Quality & $\begin{array}{l}\text { KAP Big 4/not Big } \\
\text { four }\end{array}$ & Nominal & Secondary & LK* \\
(X5) Auditor change & $\begin{array}{l}\text { Qualified/Unqualifi } \\
\text { ed openion }\end{array}$ & Nomimal & Secondary & LK* \\
\hline$L K^{*}=$ Notes of Financial Statements & & \\
\hline
\end{tabular}

The population in this study are manufacturing companies listed on the Indonesia Stock Exchange. The researcher took the population from the basic and chemical industrial sector, as many as 66 companies and the sample was 43 companies per year in the 2014 2015, 2016 observation years. So that the amount of data $(n)$ is $43 \times 3$ years $=129$ data. Sampling in this study used a purposive sampling method, namely the selection of a non-random sample whose information was obtained with certain considerations (Dewantoro, 2019). The data collected in this study will be analyzed quantitatively using the following methods (Sugiyono, 2017):

a. Descriptive statistics

Descriptive statistics are used to describe the variables in this study. The analytical tool used is the mean (mean) and standard deviation.

b. Hypothesis testing

Hypothesis testing was done by using multivariate test using logistic regression. Logistic regression is used to test whether the variables of debt to equity ratio, profitability, firm size, auditor quality, and auditor turnover affect the timeliness of financial reporting. This analytical technique no longer requires normality tests and classical assumption tests on the independent variables (Ndangi et al., 2019).

The logistic regression model used in this study is as follows:

$$
L n=\frac{p}{1-p}=\beta_{0}+\beta_{1} D E R+\beta_{2} R O A+\beta_{3} S I Z E+\beta_{4} K A P+\beta_{5} A U D C H
$$

Information:

$L n=\frac{p}{1-p}$ : Dummy variable on timeliness (category 0 for companies that are not on time and category 1 for companies that are on time).

DER : Debt to equity ratio

ROA : Return on Asset

SIZE : Company Size 
KAP : Auditor quality at Public Accounting Firm = KAP (a dummy variable, KAP partnering with The Big Four = 1, KAP not partnering with The Big Four =0)

AUDCH : Auditor Change

Analysis of testing with logistic regression according to Ghozali (in Dwiyanti, 2010) pays attention to the following matters:

a. Assessing the Feasibility of the Regression Model

The first analysis is to assess the feasibility of the logistic regression model to be used. The feasibility test of the logistic regression model was carried out using the Goodness of fit test as measured by the Chi-Square value at the bottom of the Homser and Lemeshow test.

Decision making basis: Pay attention to the goodness of fit test value as measured by the chi square value at the bottom of the Hosmer and Lemeshow test:

- If probability $>0.05$ then $\mathrm{HO}$ is accepted

- If probability $<0.05$ then $\mathrm{HO}$ is rejected

b. Overall Model Fit

The next step is to test the entire regression model (overall model fit). The test is done by comparing the value between -2 Log Likelihood (-2LL) at the beginning (Block Number = 0 ) with a value of -2 Log Likelihood $(-2 L L)$ at the end (Block Number $=1$ ). The existence of a reduction in the value between the initial $-2 L L$ and $-2 L L$ values in the next step indicates that the hypothesized model fits the data (Ghozali, 2007)

c. Testing the Regression coefficient

In testing the regression coefficient, it is necessary to pay attention to the following things:

i. $\quad$ The significance level $(\alpha)$ used is 5 percent.

Mason \& Perreault (1991) states that there is no one level of significance that can be applied to all tests.

ii. Criteria for acceptance and rejection of the hypothesis are based on the significance of the $\mathrm{p}$-value (probabilitas value). If $\mathrm{p}$-value $>$, then the alternative hypothesis is rejected, otherwise if $p$-value $>$ then the alternative hypothesis is accepted.

\section{Result and Discussion}

\section{Descriptive Statistical Analysis}

Descriptive statistical analysis for the variables DER, ROA, SIZE, KAP and AUDCH for companies that are timely in submitting the company's financial statements as a whole is presented in table 2. 
Table 2. Descriptive Statistics

\begin{tabular}{lrrrrr}
\hline & $N$ & Minimum & Maximum & Mean & Std. Deviation \\
\hline DER & 43 & $-4,95$ & 20,49 & 3,8823 & 4,47601 \\
ROA & 43 &,- 88 &, 62 &, 1277 &, 24650 \\
SIZE & 43 & 37,14 & 88,71 & 65,4205 & 16,05169 \\
KAP & 43 &, 00 & 3,00 & 1,2558 & 1,44902 \\
AUDCH & 43 &, 00 & 3,00 &, 6744 & 1,04017 \\
Valid N (listwise) & 43 & & & & \\
\hline
\end{tabular}

Source: Secondary data that has been processed

From table 2 , it can be seen that the overall value shows that the Debt to equity ratio (DER) variable has an average value (mean) of 3.8823 and a standard deviation of 4.47601. Profitability variable (ROA) has an average value (mean) of .1277 and a standard deviation of .24650. Firm Size Variable (SIZE) has an average value (mean) of 65.4205 and a standard deviation of 16.05169. Auditor Quality Variable (KAP) has an average value (mean) of 1.2558 and a standard deviation of 1.44902. While the auditor turnover variable (AUDCH) has an average value (mean) of .6744 and a standard deviation of 1.04017. According to the description above, it can be interpreted that the average value (mean) for companies that are on time is a feasible model.

Simultaneous Influence Analysis

To see the results of the simultaneous influence can be seen in the following SPSS output results:

Table 3. Iteration History

\begin{tabular}{llll}
\hline Iteration & -2 Log likelihood & Coefficients Constant \\
& 1 & 32.131 & -1.535 \\
\multirow{4}{*}{ Step 0 } & 2 & 30.938 & -1.953 \\
& 3 & 30.912 & -2.026 \\
& 4 & 30.912 & -2.028 \\
& 5 & 30.912 & -2.028
\end{tabular}

a. Constant is included in the model.

b. Initial -2 Log Likelihood: 30,912

c. Estimation terminated at iteration number 5 because parameter estimates changed by less than, 001 . 
Table 4. Iteration History

\begin{tabular}{|c|c|c|c|c|c|c|c|c|}
\hline & \multirow{2}{*}{$\begin{array}{c}-2 \text { Log } \\
\text { likelihood }\end{array}$} & \multicolumn{6}{|c|}{ Coefficients } \\
\hline \multicolumn{2}{|c|}{ Iteratıon } & & Constant & DER & ROA & SIZE & KAP & AUDC \\
\hline \multirow{7}{*}{ Step 1} & 1 & 28.686 & -1.640 & -.044 & -1.165 & .011 & -128 & -227 \\
\hline & 2 & 25.375 & -2.258 & -.093 & -1.947 & .021 & -.250 & -.513 \\
\hline & 3 & 24.717 & -2.499 & -.143 & -2.392 & .027 & -.314 & -.787 \\
\hline & 4 & 24.648 & -2.491 & -.168 & -2.616 & .028 & -.323 & -.931 \\
\hline & 5 & 24.646 & -2.475 & -.173 & -2.662 & .028 & -.322 & -.958 \\
\hline & 6 & 24.646 & -2.475 & -.173 & -2.663 & .028 & -.322 & -.958 \\
\hline & 7 & 24.646 & -2.475 & -.173 & -2.663 & .028 & -.322 & -.958 \\
\hline
\end{tabular}
a. Method: Enter
b. Constant is included in the model.
c. Initial -2 Log Likelihood: 30,912
d. Estimation terminated at iteration number 7 because parameter estimates changed by less than ,001.

Through the two Iteration History tables above we can calculate the value of -2(L0-L1) as follows: $-2\left(L_{0}-L_{1}\right)=30.912-24.646=6.266$

with $\alpha=0,05$ dan degree of freedom $(\mathrm{df})=\mathrm{k}=5$, where $\mathrm{k}$ is the number of predictor variables, the value of ${ }^{2}(p)$ from the chi-square distribution table is 11.07048 . Due to $6.266<11.07048$ or $2(L 0-L 1)<{ }^{2}(p)$, it can be concluded that together (simultaneously), the five predictor variables (DER, ROA, SIZE, KAP, AUDCH)does not have a significant effect on the Timeliness of Financial Reporting variables.

Model Feasibility Test (Goodness of fit)

The fit model can be tested with Hosmer and Lemeshow's Goodness of fit which tests the null hypothesis that the empirical data fit or fit the model. If the Hosmer-Lemeshow value is significant or less than 0.05 , the null hypothesis is rejected and the model is said to be unfit. Conversely, if it is not significant, the null hypothesis cannot be rejected, which means that the empirical data is the same as the model or the model is said to be fit. Based on the results of SPSS calculations, the results of Hosmer-Lemeshos are obtained as follows:

Table 5. Hosmer and Lemeshow Test

\begin{tabular}{lrrrr}
\hline Step & Chi-square & df & & \multicolumn{1}{c}{ Sig. } \\
\hline 1 & 6.003 & 8 & .647 \\
\hline
\end{tabular}

Based on the results of the SPSS Version 22 output, it shows that the results of the Hosmer and Lemeshow Test are 6.003 and significant at 0.647 because the value is above 0.05 , the model is said to be fit and the model can be accepted. 
Determination Test (Contribution of Independent Variables to the Bound Variable)

To see the contribution of the independent variables (DER, ROA, SIZE, KAP, and AUDCH) to TW $(Y)$ can be seen in the Summary Model of SPSS output results as follows:

Table 7. Model Summary

\begin{tabular}{cc}
\hline-2 Log likelihood & Cox \& Snell R Square \\
\hline $24.646^{\mathrm{a}}$ & .136 \\
\hline
\end{tabular}

a. Estimation terminated at iteration number 7 because parameter estimates changed by less than, 001 .

Cox \& Snell R Square column values and Nagelkerke R Square column values were used to assess model fit. The Cox \& Snell R Square value is 0.136 and the Nagelkerke $R$ Square value is 0.264 , this indicates that the dependent variable (TW) can be explained by the independent variables (DER, ROA, Size, KAP and AUDCH) of 0.264 or $26.4 \%$ while the remaining $73.6 \%$ explained by other variables outside the five independent variables studied.

Parameter Estimation (Logistic Regression Equation)

To see the parameter results and the interpretation of the logistic regression equation, it can be seen in the SPSS output results on Variables in the Equation as follows:

Table 8. Variables in the Equation

\begin{tabular}{|c|c|c|c|c|c|c|c|c|c|}
\hline & & \multirow[t]{2}{*}{ B } & \multirow[t]{2}{*}{ S.E. } & \multirow[t]{2}{*}{ Wald } & \multirow[t]{2}{*}{$d f$} & \multirow[t]{2}{*}{ Sig. } & \multirow[t]{2}{*}{$\operatorname{Exp}(B)$} & \multicolumn{2}{|c|}{ 95\% C.I.for EXP(B) } \\
\hline & & & & & & & & Lower & Upper \\
\hline \multirow{6}{*}{ Step $1^{a}$} & DER & -.173 & .189 & .839 & 1 & .360 & .841 & .581 & 1.218 \\
\hline & ROA & -2.663 & 2.193 & 1.474 & 1 & .225 & .070 & .001 & 5.132 \\
\hline & SIZE & .028 & .041 & .458 & 1 & .498 & 1.028 & .949 & 1.115 \\
\hline & KAP & -.322 & .439 & .538 & 1 & .463 & .724 & .306 & 1.714 \\
\hline & AUDCH & -.958 & .837 & 1.309 & 1 & .253 & .384 & .074 & 1.980 \\
\hline & Constant & -2.475 & 3.216 & .592 & 1 & .442 & .084 & & \\
\hline
\end{tabular}

a. Variable(s) entered on step 1: DER, ROA, SIZE, KAP, AUDCH.

Based on the results of the calculation of the variables in the equation, the logistic regression equation is obtained as follows:

$$
\operatorname{Ln} \frac{p}{1-p}=-2.475-0.173 D E R-2.663 R O A+0.028 S I Z E-0.322 K A P-0.958 A U D C H
$$

Based on this equation, the variables DER, ROA, SIZE, KAP and AUDCH are not significant $(>0.05)$. From the logistic regression equation, it can be seen that manufacturing companies on the Indonesia Stock Exchange are not punctual in their financial reporting, where the results of the average equation show negative and insignificant results. Overall this equation can be 
concluded that the higher the DER, ROA, SIZE, KAP and AUDCH values, the more timely financial reporting will be and vice versa if DER, ROA, SIZE, KAP and AUDCH show negative (low) values, it will show the timeliness of the company's financial reporting.

\section{Discussion}

Debt to Equity Ratio has an effect on the timeliness of the company's financial reporting.

The company's debt variable as measured by the debt to equity ratio (DER) shows a negative coefficient value of -.173 with a significant variable of $0.360>0.05$. This means that it can be concluded that $\mathrm{H} 1$ is rejected. Thus, it is not proven that the company's debt affects the timeliness of the company's financial reporting. These results are consistent with research by Dwiyanti, (2010); Budiyanto \& Aditya (2017) and Utami \& Yennisa (2017), that DER has no effect because DER is not the only benchmark affecting the timeliness of financial reporting.

Profitability affects the timeliness of the company's financial reporting.

The profitability variable as measured by Return on Assets (ROA) shows a positive coefficient value of -2.663 with a significant variable of $0.225>0.05$ ( 5 percent). This means that it can be concluded that $\mathrm{H} 2$ is rejected. Thus, it is not proven that probability affects the timeliness of the company's financial reporting. These results are consistent with the research of (Budiyanto \& Aditya (2017); Nurmiati (2016); Utami \& Yennisa (2017) that ROA has no effect because ROA is not the only benchmark affecting the timeliness of financial reporting.

Company size affects the timeliness of the company's financial reporting.

Firm Size variable shows a positive coefficient value of 0.028 with a significant variable of $0.498>0.05$. This means that it can be concluded that $\mathrm{H} 3$ is rejected. Thus, it is not proven that the size of the company affects the timeliness of the company's financial reporting. These results are consistent with research by Magdalena and Peni (2012); (Nurmiati, 2016) that, SIZE has no effect because SIZE is not the only measure that affects the timeliness of financial reporting.

Auditor quality affects the timeliness of the company's financial reporting.

Auditor quality variable (KAP) shows a negative coefficient value of -0.322 with a significant variable of $0.463>0.05$. This means that it can be concluded that $\mathrm{H} 4$ is rejected. Thus it is proven that the Quality of Auditor (KAP) has no effect on the timeliness of the company's financial reporting. This result is consistent with research by Dwiyanti (2010) and Budiyanto \& Aditya (2017) that KAP has no effect because KAP is not the only benchmark affecting the timeliness of financial reporting. 
Auditor change affects the timeliness of the company's financial reporting.

The auditor turnover variable shows a negative coefficient value of 0.958 with a significant variable of $0.253>0.05$. This means that $\mathrm{H} 5$ is rejected, thus it is not proven that the change of auditors affects the timeliness of the company's financial reporting. These results are consistent with research by Dwiyanti (2010) that AUDCH has no effect, because AUDCH is not the only measure that affects the timeliness of financial reporting.

\section{Conclusion}

This study aims to find empirical evidence about the factors that affect the timeliness of financial reporting of manufacturing companies in Indonesia by using a sample of 43 companies in three years from 2014, 2015, 2016, so that the number of samples (n) is 43 x $3=129$ data. From the results of data research and discussion carried out, the following conclusions are obtained: 1)The research object consists of 43 companies on time in a row in 2014 - 2016. Overall, companies are on time in financial reporting to Bapepam. 2) The results of the logistic regression test show empirical evidence that DER, ROA, SIZE, KAP and AUDCH simultaneously have no effect on the timeliness of financial reporting. Suggestions for future research are: 1) Expanding the research by adding research samples from all companies listed on the Indonesia Stock Exchange and a longer observation period so that the results obtained will be more generalizable and will better describe the actual conditions over the long term. 2) Adding other variables that are suspected to affect the timeliness of financial reporting such as the quality of the internal control system, audit opinion, and the role of the company's internal audit.

\section{References}

Arniman Zebua, Selfie Gultom, \& Yohannes. (2020). Analisis Faktor-Faktor Yang Mempengaruhi Ketepatan Waktu Pelaporan Keuangan Pada Perusahaan Manufaktur Yang Terdaftar Di Bursa Efek Indonesia. Jurnal Akuntansi Bisnis Eka Prasetya : Penelitian IImu Akuntansi, 6(1), 88-101. https://doi.org/10.47663/abep.v6i1.47

Budiyanto, S., \& Aditya, E. M. (2017). Faktor-Faktor yang Mempengaruhi Ketepatan Waktu Pelaporan Keuangan (Studi Empiris Perusahaan Food and Beverages Periode 2010-2012). $\begin{array}{lll}\text { Fokus } \quad \text { Ekonomi, 10(1), } & \text { 77-87. }\end{array}$ https://www.ejournal.stiepena.ac.id/index.php/fe/article/viewFile/74/71

Dewantoro, A. (2019). Pengaruh Optimisme terhadap Kemampuan Identifikasi Peluang Mahasiswa Strata Satu Pada Perguruan Tinggi Di Surabaya. Agora, 7(1), 6. https://media.neliti.com/media/publications/287040-pengaruh-optimisme-terhadapkemampuan-id-f17b17dc.pdf

Dewi, I. G. A. R. P., Putri, P. Y. A., \& Idawati, P. D. P. (2019). PENGARUH KETIDAKTEPATWAKTUAN PELAPORAN KEUANGAN BERPENGARUH PADA REAKSI PASARPERUSAHAAN MANUFAKTUR 
YANG TERDAFTAR DI BURSA EFEK INDONESIA TAHUN 2016-2017. KRISNA: Kumpulan Riset Akuntansi, $\quad 10(2 \quad$ SE-Articles), $177-187$. https://www.ejournal.warmadewa.ac.id/index.php/krisna/article/view/913

Dwiyanti, R. (2010). ANALISIS FAKTOR-FAKTOR YANG MEMPENGARUHI KETEPATAN WAKTU PELAPORAN KEUANGAN PADA PERUSAHAAN MANUFAKTUR YANG TERDAFTAR DI BURSA EFEK INDONESIA [Universitas Diponegoro]. http://eprints.undip.ac.id/22634/1/Skripsi_Rini_Dwiyantipdf.pdf

Ghozali, I. (2007). Aplikasi Analisis Multivariate dengan Program SPSS). Badan Penerbit Universitas Diponegoro.

Imaniar, F. Q. (2016). Faktor-Faktor Yang Mempengaruhi Ketepatan Waktu Pelaporan Keuangan Perusahaan. Jurnal IImu Dan Riset Akuntansi, 5(6), 43-56. http://jurnalmahasiswa.stiesia.ac.id/index.php/jira/article/view/334/340

Kuswanto, H., \& Manaf, S. (2013). FAKTOR-FAKTOR YANG MEMPENGARUHI KETEPATAN WAKTU PENYAMPAIAN LAPORAN KEUANGAN KE PUBLIK (STUDI EMPIRIS PADA PERUSAHAAN MANUFAKTUR YANG TERDAFTAR DI BURSA EFEK INDONESIA PERIODE 2010-2013). JURNAL EKONOMI MANAJEMEN AKUNTANSI, 22(38), 1-18. http://ejurnal.stiedharmaputrasmg.ac.id/index.php/JEMA/article/view/212

Laoli, A. N., \& Herawaty, V. (2019). PENGARUH PROFITABILITAS, GROWTH, LEVERAGE, OPERATING CYCLE DAN PRUDENCE TERHADAP KUALITAS LABA DENGAN FIRM SIZE SEBAGAI VARIABEL MODERASI. PROSIDING SEMINAR NASIONAL CENDEKIAWAN, 2000, 2. https://doi.org/10.25105/semnas.v0i0.5828

Mason, C. H., \& Perreault, W. D. (1991). Collinearity, Power, and Interpretation of Multiple Regression Analysis. Journal of Marketing Research, 28(3), 268-280. https://doi.org/10.1177/002224379102800302

Nasarudin, M. I. (2017). RISIKO INVESTASI PADA SURAT BERHARGA PASAR MODAL. Jurnal Hukum \& Pembangunan, 131. https://doi.org/10.21143/jhp.vol0.no0.1414

Ndangi, W. R. A., Resmawan, R., \& Djakaria, I. (2019). Perbandingan Analisis Diskriminan dan Regresi Logistik Multinomial. Jambura Journal of Mathematics, 1(2), 54-63. https://doi.org/10.34312/jjom.v1i2.2100

Nurmiati. (2016). Faktor-Faktor yang Mempengaruhi Penyerapan Anggaran. Fakultas Ekonomi Dan Bisnis Universitas Mulawarman, Indonesia, Jurnal Ekonomi Dan Manajemen, 13(2), 117. http://journal.feb.unmul.ac.id

Rafikaningsih, P. S. A., Putra, I. G. C., \& Sunarwijaya, I. K. (2020). Ketepatan Waktu Penyampaian Laporan Keuangan Emiten Di Bursa Efek Indonesia dan Faktor-Faktor yang Mempengaruhi. Jurnal Kharisma, 2(2), 116-136. http://ejournal.unmas.ac.id/index.php/kharisma/article/view/974 
Simangunsong, N. T. A., llat, V., \& Elim, I. (2018). ANALISIS LAPORAN ARUS KAS SEBAGAI ALAT DALAM PENGAMBILAN KEPUTUSAN MANAJEMEN PADA PT. BPR PRISMA DANA MANADO. GOING CONCERN : JURNAL RISET AKUNTANSI, 13(02), 639-648. https://doi.org/10.32400/gc.13.02.19923.2018

Sugiyono. (2017). Metode Penelitian Kuantitatif, Kualitatif, dan R\&D. CV. Alfabeta.

Sunarsih, N. M., \& Dewi, N. P. S. (2019). Pengaruh karakteristik komite audit terhadap ketepatwaktuan pelaporan keuangan perusahaan perbankan yang terdaftar di BEI. Juima, 9(1), 13-20. https://doi.org/https://doi.org/10.36733/juima.v9i1.467

Utami, D., \& Yennisa. (2017). Faktor-Faktor Mempengaruhi Ketepatan Waktu Pelaporan Keuangan pada Perusahaan Sub Sektor Bank di Bursa Efek Indonesia. Akuntansi Dewantara, 1(1), 31-38. https://doi.org/https://doi.org/10.26460/ad.v1i1.22

Wardani, L. (2017). ANALISIS FAKTOR-FAKTOR YANG MEMPENGARUHI AUDIT DELAY (Studi Empiris pada Perusahaan yang Terdaftar Sebagai Anggota LQ45 di BEI Periode 2010-2015) [Universitas Mercu Buana Yogyakarta]. http://eprints.mercubuana-yogya.ac.id/50/1/Cover dan lampiran.pdf 